\title{
Use of CT-Scan for Predicting Mortality of Acute Intracerebral Haemorrhagic Stroke within 7 and 28 Days
}

\author{
Md. Durrul Huda', Niranjan Kumar Sana², Quamruddin Ahmad³, Md. Kafil Uddin', Md.

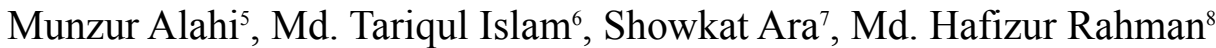

\begin{abstract}
${ }^{1}$ Assistant Professor, Department of Radiology \& Imaging, Institute of Health Technology, Rajshahi, Bangladesh; ${ }^{2}$ Professor, Department of Biochemistry \& Molecular Biology, University of Rajshahi, Bangladesh; ${ }^{3}$ Professor \& Head, Department of Neurology, Holy Family Red Crescent Medical College, Dhaka, Bangladesh; ${ }^{4}$ Associate Professor \& Head, Department of Neurology, Rajshahi Medical College and Hospital, Rajshahi, Bangladesh; ${ }^{5}$ Assistant Professor, Department of Neurology,

Rajshahi Medical College, Rajshahi, Bangladesh; ${ }^{6}$ Assistant Professor, Department of Neuroradiology \& Imaging,

National Institute of Neuroscience, Dhaka, Bangladesh; ${ }^{7}$ Associate Professor, Department of Neuroradiology \& Imaging, National Institute of Neurosciences \& Hospital, Dhaka, Bangladesh; ${ }^{8}$ Associate Professor \& Head, Department of Radiology \& Imaging, Rajshahi Medical College. Rajshahi, Bangladesh
\end{abstract}

[Received: : 12 October 2018; Accepted: 2 November 2018; Published: 1 January 2019]

\begin{abstract}
Background: Recognition of factors affecting morbidity and mortality of a disease helps in the proper management of a disease. CT scan of Brain is an essential investigation for all stroke patients. Identifying different characteristics of the CT findings of stroke patients which affect morbidity and mortality will help in the specific management of stroke patients. Thus this study was done to identify such factors from CT scan of Brain which will help in the proper management of stroke patients. Objectives: The aim of this present study was to determine the $7^{\text {th }}$ and $28^{\text {th }}$ days' mortality rate of acute intracerebral hemorrhagic stroke and to determine the predictors of mortality. Methodology: Consecutive CT scan proven stroke patients following ICH were studied in the department of Radiology \& Imaging at Rajshahi Medical College, Rajshahi, Bangladesh in collaboration with the Department of Neurology of Rajshahi Medical College, Rajshahi from January 2012 to December 2013. Site, size and volume of haematoma, midline shift, pineal gland displacement, hydrocephalus and intraventricular extension of haemorrhage were correlated with the mortality within $7^{\text {th }}$ and $28^{\text {th }}$ days of acute stroke. Risk factors like hypertension, smoking, diabetes and alcoholism were also recorded. Result: Ninety-nine consecutive CT scan proven stroke patients following ICH were studied. The 28 -day mortality of intracerebral hemorrhage was $44.44 \%$ and it was $29.30 \%$ within the first 7 days of onset. Maximum number of death occurred in brainstem haemorrhage $(75 \%)$, initial haematoma volume 61 to $80 \mathrm{ml}(89.47 \%),>80 \mathrm{ml}(91.7 \%)$, pineal gland displacement $>3 \mathrm{~mm}(79.5 \%)$, septum pellucidum displacement $>5 \mathrm{~mm}(72.4 \%)$, ventricular extension $(88.57 \%)$, and hydrocephalus (76.74\%). Conclusion: The present study shows that deaths within 7th and 28th day of acute haemorrhagic stroke are correlated with the initial CT findings which could be regarded as a good predictor of mortality. [Journal of National Institute of Neurosciences Bangladesh, 2019;5(1): 42-46]
\end{abstract}

Keywords: Stroke, Intracerebral haemorrhage, Mortality, CT scan of brain

Correspondence: Dr. M. Durrul Huda, Assistant Professor, Department of Radiology \& Imaging, Institute of Health Technology, Rajshahi, Bangladesh; Email: durruldr68@gmail.com; Cell no.01715804433

Conflict of interest: There is no conflict of interest relevant to this paper to disclose.

Funding agency: This research project was not funded by any group or any institution.

Contribution to authors: Professor Quamruddin Ahmad and Professor Niranjan Kumar Sana contributed from the protocol preparation, data collection up to report writing. Manuscript writing was performed by Mir shariful Islam. Statistical analysis was performed by Dr. Md. Mozidul Haque PhD involved in supervision of the research work and revision of manuscript.

How to cite this article: Huda MD, Sana NK, Ahmad Q, Uddin MK, Alahi MM, Islam MT, Rahman MH. Use of CT-Scan for Predicting Mortality of Acute Intracerebral Haemorrhagic Stroke within 7 and 28 Days. J Natl Inst Neurosci Bangladesh, 2019;5(1): $42-46$

Copyright: (C2019. Huda et al. Published by Journal of National Institute of Neurosciences Bangladesh. This article is published under the Creative Commons CC BY-NC License (https://creativecommons.org/licenses/by-nc/4.0/). This license permits use, distribution and reproduction in any medium, provided the original work is properly cited, and is not used for commercial purposes.

\section{Introduction}

Intracerebral haemorrhage (ICH) is referred to as bleeding in the brain parenchyma itself. It is the most common type of non traumatic intracranial haemorrhage and an important cause of stroke, especially in Asians and Blacks. It accounts for 10 to 15 percent of all strokes 
in Whites and about 30 percent in Blacks and individuals of Asian origin. It is a major cause of morbidity and mortality of stroke'.

Brain imaging is the cornerstone for diagnosis of ICH. Although MRI is an excellent tool for considerable information on the process of acute stroke; MRI is not readily available to the most patients presented with acute stroke in a rural or community hospital. CT scan is the imaging modality of choice in patients presented with acute stroke, which can detect ICH within few minutes of onset of stroke ${ }^{2}$. It is safe and non-invasive, helps to measure the hematoma size, location of the hemorrhage and the presence of intraventricular, subarachnoid or subdural blood, or to find out any mass effect in primary non-traumatic ICH. All these pieces of information are extremely useful in assessing the clinical and functional outcome in acute $\mathrm{ICH}$, which cannot be obtained by clinical examination itself ${ }^{3}$. It is useful for the physician to predict the functional outcome from a first CT scan of the brain done at the time of the hospital admission. The purpose of this study is to find out how we can predict a short-term in-hospital mortality and morbidity from these CT scan findings; how hematoma volume, location of stroke, midline shift, intraventricular extension of bleed, ventricle compression influence the clinical outcome in patients with acute stroke.

\section{Methodology}

This cross-sectional observational study was performed in different private clinics of Rajshahi, Bangladesh and the Department of Radiology \& Imaging, Rajshahi Medical College Rajshahi in collaboration with the Department of Neuromedicine of Rajshahi Medical

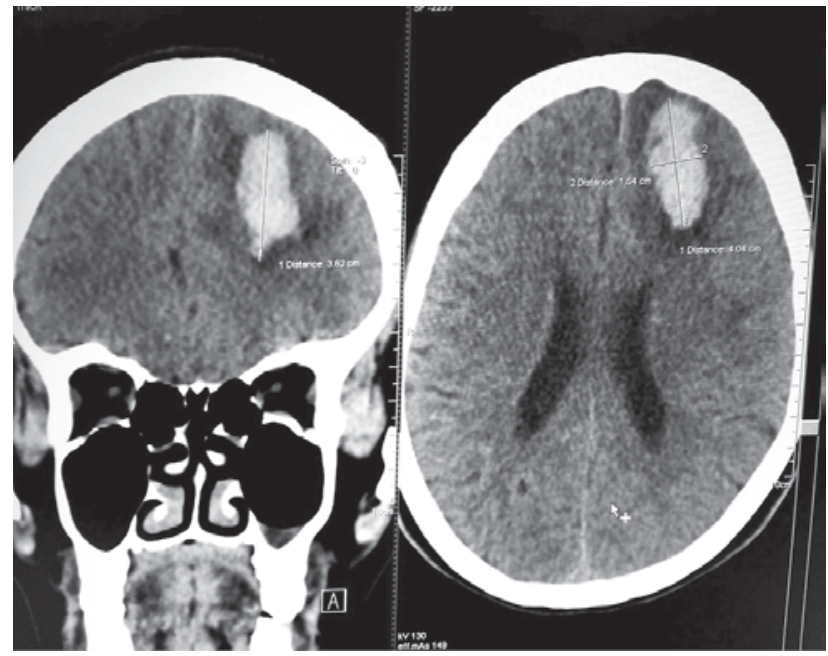

Figure I: Measurement of volume of intracerebral haemorrhage.
College, Rajshahi, Bangladesh from January 2012 to December 2013 for a period of two (02) years. The study population was comprised of total 99 patients who had definite evidence of first ever acute intracerebral haemorrhage and were diagnosed by computed tomography (CT). Informed consent was taken approved by institutional ethical committee of Rajshahi Medical College, Rajshahi. Data was collected on the basis of inclusion and exclusion criteria, with irrespective of sex in OPD or the ward, of department of Neuromedicine of Rajshahi Medical College, Rajshahi. Following patients were excluded from the study like patients who had prior stroke with established neuro-deficit, patients who had time gap from the onset of stroke to the presentation to the hospital been more than 24 hours, patients who had hemorrhagic stroke due to trauma, sub-arachnoid hemorrhage and rupture aneurysm. Non-contrast CT-scan was done within 24 hours of suspected acute stroke. After completion of CT-scan volume of hematoma which was computed by getting the product of $\mathrm{L} \times \mathrm{W} \times \mathrm{AP} \times 0.523$ where $\mathrm{L}$ was the vertical diameter showing hematoma on CT scan, $\mathrm{W}$ was the greatest transverse diameter of the bleed, AP was the greatest antero-posterior diameter of the hematoma perpendicular to $\mathrm{W}$ and 0.523 was a constant factor (Figure I), location of stroke, presence of intraventricular extension of bleed, midline shift and presence of hydrocephalus were obtained.

\section{Results}

A total of 99 cases were included in the study. The age of the subjects ranged from 35 to 86 years with a mean age of 59.62(+12) years. Male-female ratio was 1.7:1. Majority of the patients were between 51 to 70 years and representing $68.42 \%$. Hypertension was the most common $(82.12 \%)$ risk factor. Other risk factors were chronic smoking $(23.20 \%)$ and diabetes mellitus $(18.25 \%)$. The site of ICH were $61(61.62 \%)$ in capsulogangloinic region followed by lobar $17(17.17 \%)$, thalamus $10(10.11 \%)$, cerebellum $7(7.07 \%)$, brainstem $4(4.04 \%)$. Total death was 31 $(50.82 \%)$ in capsulogangloinic region, $2(11.76 \%)$ in lobar haemorrhage, $7(70.00 \%)$ in thalamic region, $75.00 \%$ in brainstem and $14.29 \%$ in cerebellar haemorrhage Total death was $44(44.44 \%)$ in 28 days and most common site for death was brainstem, thalamus and capsuloganglionic region in order of frequency. $\mathrm{P}$ value was significantly higher and it was 0.018 (Table 1). 
Table 1: Mortality by site $(\mathrm{n}=99)$

\begin{tabular}{|c|c|c|c|c|c|}
\hline \multirow[t]{2}{*}{ Site } & \multirow{2}{*}{$\begin{array}{c}\text { No. of patient } \\
(\%)\end{array}$} & Within 7 days & $8^{\text {th }}$ to $28^{\text {th }}$ days & Total death & \multirow{2}{*}{$\begin{array}{c}\mathbf{P} \\
\text { value }\end{array}$} \\
\hline & & No. of death (\%) & No. of death (\%) & (Within 28 days) & \\
\hline Capsulogangloinic & $61(61.62)$ & $21(34.42)$ & $10(16.39)$ & $31(50.81)$ & \multirow{6}{*}{0.018} \\
\hline Lobar & $17(17.18)$ & $1(5.88)$ & $1(5.58)$ & $2(11.76)$ & \\
\hline Thalamus & $10(10.11)$ & $5(50.0)$ & $2(20.0)$ & $7(70.00)$ & \\
\hline Cerebellum & $7(7.07)$ & $0(0.0)$ & $1(14.29)$ & $1(14.29)$ & \\
\hline Brainstem & $4(3.57)$ & $2(50.0)$ & $1(25.0)$ & $3(75.0)$ & \\
\hline Total & $99(100)$ & $29(29.30)$ & 15 (15.15) & $44(44.44)$ & \\
\hline
\end{tabular}

$P$ value 0.018 means significantly higher at $(\mathrm{p}<0.05)$.

Table 2: Volume of haemorrhage and mortality of ICH $(n=99)$

\begin{tabular}{|c|c|c|c|c|c|}
\hline \multirow[t]{2}{*}{ Volume $(\mathrm{mL})$} & \multirow{2}{*}{$\begin{array}{c}\text { No. of patient } \\
99(\%)\end{array}$} & Within 7 days & $8^{\text {th }}$ to $28^{\text {th }}$ days & \multirow{2}{*}{$\begin{array}{c}\text { Total death } \\
\text { (Within } 28 \text { days) }\end{array}$} & \multirow{2}{*}{$\begin{array}{c}\mathbf{P} \\
\text { value }\end{array}$} \\
\hline & & No. of death (\%) & No. of death $(\%)$ & & \\
\hline Upto 40 & $45(45.45)$ & $3(6.67)$ & $2(4.44)$ & $5(11.11)$ & \\
\hline 41 to 60 & $23(23.23)$ & $6(26.09)$ & $5(21.74)$ & $11(47.83)$ & \\
\hline 61 to 80 & 19(19.19) & $10(52.63)$ & $7(36.84)$ & $17(89.47)$ & 0.011 \\
\hline More Than 80 & $12(12.12)$ & $10(83.33)$ & $1(8.33)$ & 11(91.67) & \\
\hline
\end{tabular}

P value 0.011 means significantly higher at $(\mathrm{p}<0.05)$.

Of the 60 patients whose CT detected pineal gland without displacement or displacement upto $3 \mathrm{~mm}$ total death was $13(21.67 \%)$ within 28 days. Pineal gland displacement $>3 \mathrm{~mm}$ was found in $39(39.39 \%)$ and total death was $31(79.49 \%)$ within 28 days and it was statistically significant ( $\mathrm{p}$ value 0.028 ). The highest number of death was from pineal gland displacement $>3 \mathrm{~mm}$ and within 7 days (Table 3 ).

Septum pellucidum displacement upto $5 \mathrm{~mm}$ or without displacement was found in $70(70.54 \%)$ patients and total death was 23 (32.86\%) within 28 days. Septum pellucidum displacement $>5 \mathrm{~mm}$ was found in $29(29.29 \%)$ and total death was $21(72.42 \%)$ within 28 days and it was statistically significant ( $\mathrm{p}$ value 0.033 ) (Table 4).

Intraventricular extension of haemorrhage was found in $35(35.35 \%)$ patients and total death was $31(88.57 \%)$ within 28 days. There was no extension of haemorrhage in intraventricular location in 64(64.65\%) patients and total death was $13(25.71 \%)$ within 28 days. It was statistically significant ( $\mathrm{p}$ value 0.017 ) (Table 5).

Table 3: Mass effect of haemorrhage mortality by pineal gland displacement $(n=99)$

\begin{tabular}{|c|c|c|c|c|c|}
\hline $\begin{array}{l}\text { Pineal gland } \\
\text { displacement }\end{array}$ & $\begin{array}{c}\text { No. of patient } \\
99(\%)\end{array}$ & $\begin{array}{c}\text { Within } 7 \text { days } \\
\text { No. of death }(\%)\end{array}$ & $\begin{array}{c}8^{\text {th }} \text { to } 28^{\text {th }} \text { days } \\
\text { No. of death }(\%)\end{array}$ & $\begin{array}{c}\text { Total death } \\
\text { (Within } 28 \text { days) }\end{array}$ & $\begin{array}{c}P \\
\text { value }\end{array}$ \\
\hline upto $3 \mathrm{~mm}$ & $60(60.61)$ & $7(11.67)$ & $6(10.00)$ & $13(21.67 \%)$ & \\
\hline More than $3 \mathrm{~mm}$ & $39(39.39)$ & $22(56.41)$ & $9(23.08)$ & $31(79.49 \%)$ & 0.028 \\
\hline
\end{tabular}

$\mathrm{P}$ value reached from chi square test. The difference was significant $(\mathrm{p}<0.05)$ between two groups.

Table 4: Mass effect of haemorrhage mortality by septum pellucidum displacement $(\mathrm{n}=99)$

\begin{tabular}{|c|c|c|c|c|c|}
\hline \multirow{2}{*}{$\begin{array}{l}\text { Septum pellucidum } \\
\text { displacement }\end{array}$} & \multirow{2}{*}{$\begin{array}{c}\text { No. of patient } \\
(\%)\end{array}$} & Within 7 days $(n=29)$ & $8^{\text {th }}$ to $28^{\text {th }}$ days $(n=15)$ & \multirow{2}{*}{$\begin{array}{c}\text { Total death } \\
\text { (Within } 28 \text { days) }\end{array}$} & \multirow{2}{*}{$\begin{array}{c}\mathbf{P} \\
\text { value }\end{array}$} \\
\hline & & No. of death (\%) & No. of death (\%) & & \\
\hline upto $5 \mathrm{~mm}$ & $70(70.71)$ & $7(11.67)$ & $8(11.43)$ & $23(32.86 \%)$ & \\
\hline$>5 \mathrm{~mm}$ & $29(29.29)$ & $22(56.41)$ & $7(24.14)$ & $21(72.42 \%)$ & 0.033 \\
\hline
\end{tabular}

$P$ value reached from chi square test. The difference was significant $(p<0.05)$ between two groups

Table 5: Ventricular extension of the haemorrhage $(n=99)$

\begin{tabular}{|c|c|c|c|c|c|}
\hline \multirow{2}{*}{$\begin{array}{l}\text { Ventricular } \\
\text { extension }\end{array}$} & \multirow{2}{*}{$\begin{array}{c}\text { No. of patient } \\
(\%)\end{array}$} & Within 7 days $(n=31)$ & $8^{\text {th }}$ to $28^{\text {th }}$ days $(n=18)$ & \multirow{2}{*}{$\begin{array}{c}\text { Total death } \\
\text { (Within } 28 \text { days) }\end{array}$} & \multirow{2}{*}{$\begin{array}{c}\mathbf{P} \\
\text { value }\end{array}$} \\
\hline & & No. of death (\%) & No. of death (\%) & & \\
\hline No & $64(64.65)$ & $7(10.94)$ & $6(9.38)$ & $13(25.71 \%)$ & \\
\hline Yes & $35(35.35)$ & $22(62.86)$ & $9(25.71)$ & $31(88.57 \%)$ & 0.017 \\
\hline
\end{tabular}

$P$ value reached from chi square test. The difference was significant $(\mathrm{p}<0.05)$ between two groups. 
Table 6: Correlation of hydrocephalus and mortality in haemorrhagic stroke (n=99)

\begin{tabular}{|c|c|c|c|c|c|}
\hline Hydrocephalus & No. of patient & Within 7 days $(n=29)$ & $8^{\text {th }}$ to $28^{\text {th }}$ days $(n=15)$ & Total death & $\mathbf{P}$ \\
\hline & $99(\%)$ & No. of death (\%) & No. of death (\%) & (Within 28 days) & \\
\hline No & $56(56.57)$ & $8(14.29)$ & $4(7.14)$ & $12(21.43)$ & \\
\hline Yes & $43(43.43)$ & $21(48.84)$ & $11(25.55)$ & $33(76.74)$ & 0.018 \\
\hline
\end{tabular}

$P$ value reached from chi square test. The difference was significant $(p<0.05)$ between two groups.

Hydrocephalus present in haemorrhagic stroke was in $43(43.43 \%)$ patients and total death was $32(74.42 \%)$ within 28 days. There was no hydrocephalus in 56 $(56.57 \%)$ patients and total death was $12(21.43 \%)$ within 28 days. $\mathrm{P}$ value was 0.018 and it was statistically significant (Table 6).

\section{Discussion}

Stroke due to intracerebral haemorrhage is an important cause of death. It is not possible to differentiate reliably between intracranial haemorrhage and infarction on the basis of clinical features alone $e^{4}$. For diagnosing and differentiating the type of stroke as early as possible, computed tomography (CT) scanning of the brain is the gold standard investigation and in practice most stroke patients should ideally have a CT scan done ${ }^{5}$.

Present study showed that majority of the subjects belonged to the age group of 51 to 70 years comprising $68.42 \%$ with a mean age of 59.62 years, which is comparable to the study by Singh et $\mathrm{al}^{1}$. Male female ratio was 1.7:1. Similar study was also observed by Singh et al ${ }^{1}$.

Hypertension was found to be the commonest risk factor $(82.12 \%$ of the cases) in the present study. Similar observation was reported by Singh et al ${ }^{1} 78 \%$, by Douglas et $\mathrm{al}^{6}$ in $80 \%$ and $75 \%$ of ICH by Scott et $\mathrm{al}^{7}$. Cigarette smoking was associated with $\mathrm{ICH}$ in $23.20 \%$ of cases. Comparable observations were found $24.0 \%$ by Singh et $\mathrm{al}^{1}$ and $27.0 \%$ by Shinton et $\mathrm{al}^{8}$ and by Tatu et $\mathrm{al}^{9}$ in $18 \%$ of ICH cases. Diabetes was found in $18.25 \%$ of cases. Singh et $\mathrm{al}^{1}$ and Nilsson et $\mathrm{al}^{10}$ reported $6 \%$ and $10 \%$ haemorrhagic stroke in diabetic patients respectively.

The site of ICH is more common in capsulogangloinic region $61(61.62 \%)$ followed by lobar $17(17.17 \%)$. Next common site is thalamus $10(10.11 \%)$, cerebellum $7(7.07 \%)$, brainstem $4(4.04 \%)$. Total death was $44(44.44 \%)$ in 28 days and most common site for death was brainstem, thalamus and capsuloganglionic region in order of frequency. Singh et $\mathrm{al}^{1}$ reported the sites of lesion in intracerebral haemorrhage determined by CT-scan in order of frequency in a study were basal ganglia $(65 \%)$, lobar (17\%), thalamus (13\%), pons
$(3 \%)$ and cerebellum (2\%). Feldmann ${ }^{11}$ reported the sites of involvement by ICH in order of putamen $(35 \%)$, lobar $(30 \%)$, cerebellum $(15 \%)$, thalamus $(10 \%)$ and pons $(5 \%)$. Tatu et $\mathrm{al}^{9}$ found ICH to be the most prevalent in lobar $(36.5 \%)$, followed by lentiform area $(32 \%)$, thalamic $(15.7 \%)$, cerebellar $(8.8 \%)$, midbrain and pons $(2.0 \%)$, intraventricular haemorrhage $(92.0 \%)$, caudate $(1.0 \%)$ and multiple $(2.0 \%)$. Scott et $\mathrm{al}^{7}$ in their study found that putaminal bleeding $(35.0 \%)$ was the commonest followed by lobar $(30.0 \%)$, thalamus $(10.0 \%)$, cerebellum $(15.0 \%)$, pons $(5.0 \%)$ and caudate $(5.0 \%)$. The finding in the present study is comparable with Scott et $\mathrm{al}^{7}$ except for cerebellum which is the least common site in the present study.

Haematoma volume upto $40 \mathrm{ml}$ caused death in $11.11 \%$; however, in volume of 41 to $60 \mathrm{ml}$ mortality was $47.83 \%$, in 60 to $80 \mathrm{ml}$ it was $89.47 \%$ and in $>80$ $\mathrm{ml}$ death was $91.67 \%$. Lampel ${ }^{12}$ quoted that critical lethal outcome were associated with $50 \mathrm{ml}^{13}$ or $80 \mathrm{mll}$ in lobar haemorrhage. Kase ${ }^{15}$ found lobar ICH with volume larger than $50 \mathrm{ml}$ who were comatose on admission have mortality close to $100 \%$. Similar pattern of higher mortality among the patients having larger haematoma volume was also noted in the present study with statistically significant findings. Singh et al ${ }^{1}$ found $85.2 \%$ and $90.9 \%$ mortality among the $\mathrm{ICH}$ volume greater than $60 \mathrm{ml}$ and $80 \mathrm{ml}$ respectively. Mukherjee et $\mathrm{al}^{16}$ observed $67.3 \%$ mortality among ICH volume greater than $40 \mathrm{ml}$.

Wiggins et a ${ }^{17}$ reported that $\mathrm{ICH}$ with mid line shift or pineal gland displacement $>3 \mathrm{~mm}$ showed mortality rate of $40 \%$. In the present study, ICH with pineal gland displacement $>3 \mathrm{~mm}$ shows $(79.49 \%)$ mortality rate and septum pellucidum displacement $>5 \mathrm{~mm}$ shows $72.42 \%$ morality. These differences may be due to difference in multiple risk factor incidence such as hypertension but our study matches with the study of Singh et $\mathrm{al}^{1}$ who show $70.0 \%$ mortality rate.

Intracerebral haemorrhage with intraventricular extension influenced the mortality rate of $65.0 \%$, $70.0 \%$ and $74.0 \%$ as observed by Wiggins et $\mathrm{al}^{17}$, Fieschi et $\mathrm{al}^{18}$ and Singh et $\mathrm{al}^{1}$ respectively. In the present study ICH with intraventricular extension 
influenced the mortality rate of $88.57 \%$ than without intraventricular extension of $25.71 \%$ mortality which is comparable with the above studies.

This study demonstrates the impact of hydrocephalus on outcome from ICH. Mortality was $74.43 \%$ in $\mathrm{ICH}$ with hydrocephalus and $21.43 \%$ in ICH without hydrocephalus. This present study corresponds with the study of Michael et a $1^{19}$.

The overall mortality rate of $52.0 \%$ in 30 days was reported by Bamford et $\mathrm{al}^{20}$ with $56 \%$ of the death occurring within the first 3 days of onset. In other studies, 30 days ICH mortality rate was found to be $30 \%$ by Fieschi et $\mathrm{a}^{18}$ and $35.0 \%$ by Anderson et $\mathrm{al}^{21}$. Tatu et $\mathrm{al}^{9}$ reported overall mortality of $24.2 \%$ in 30 days and death within the first 3 days constituted $48 \%$ of all deaths. In the present study over all 7 days, and 28 days, mortality rates were found to be $29.30 \%$ and $44.44 \%$ respectively which could be comparable to above studies. Similarly 30 days, mortality rate was found in the study by Frank et $\mathrm{al}^{22}$ and Singh et $\mathrm{al}^{1}$. However, Silver et $\mathrm{al}^{23}$ reported $80.0 \%$ mortality within 72 hours in their study. These differences in the mortality may be due to variations in population, risk factors, facilities availability and other factors.

Anderson et $\mathrm{al}^{21}$ reported 28 days case fatality rate among the ICH locations as $100.0 \%$ in brain stem, $30.0 \%$ in cerebellum, $22.0 \%$ in basal ganglia and thalamus, and $21.0 \%$ in lobar haemorrhage. Almost similar pattern of case fatality were also observed in the present study.

\section{Conclusion}

The present study showed that deaths within 7th and 28th day of acute haemorrhagic stroke were correlated with the initial CT findings. Mortality was increased with increasing amount of $\mathrm{CT}$ detected haemorrhage with more than $90 \%$ mortality in those having more than $80 \mathrm{ml}$ of CT detected haemorrhage. Increasing mass effect of haemorrhage as detected by significant pineal gland or septum pellucidum displacement, intraventricular extension of haemorrhage and presence of hydrocephalus also significantly increased the chance of mortality.

\section{References}

1. Singh AJ, Singh KM, Brogen AK, Singh WJ, Singh NB. CT-Scan as a Tool for Predicting Outcome of Stroke due to Intracerebral Haemorrhage at a Referral Hospital. IJPMR 2006;17(2):33-38

2. Steiner T, Petersson J, Al-Shahi Salman R, Christensen H, Cordonnier C, Csiba L, et al. European research priorities for intracerebral haemorrhage. Cerebrovasc Dis 2011;32:409-19
3. Wardlaw JM, Seymour J, Cairns J, Keir S, Lewis S, Sandercock P. Immediate computed tomography scanning of acute stroke is cost-effective and improves quality of life. Stroke 2004;35:2477-83

4. Sandercock PA, Warlow CP, Jones LN, Starkey IR. Predisposing factors for cerebral infarction. The Oxfordshire community stroke project. BMJ 1989;298:75-78

5. Donnan GA. Investigation of patient with stroke and transient ischaemic attacks. Lancet 1992;339:473-76

6. Douglas MA, Haerer AF. Long-term prognosis of Hypertensive Intracerebral Haemorrhage. Stroke 1998;13(4):488-91

7. Scott WR, Miller BR. Intracerebral haemorrhage with rapid recovery. Arch Neurol 1985;42:133-36

8. Shinton R, Beevers G. Multi analysis of relation between cigarette smoking and stroke. BMJ 1989;198:189-94

9. Tatu L, Moulin T, Mohamad RE, Vuillier F, Rumbach L, Czorny A. Primary intracerebral haemorrhages in the Besancon stroke registry. Eur Neurol 2000;43:209-14

10. Nilsson OG, Lindgren A, Stahl N, Brandt L, Saveland H. Incidence of intracerebral and subarachnoid haemorrhage. J Neurol Neurosurg Psychiatry 2000;69:601-67

11. Feldmann E. Current concepts of cerebrovascular disease and stroke-intracerebral haemorrhage. Stroke 1991;22(5):248-51

12. Lampel Y, Gilad R, Eshel Y, Pinhas IS. Neurological and functional outcome in patients with supratentorial haemorrhages A prospective study. 1995;26(12):2249-52

13. Massaro AR, Sacco R, Mohr JP. Clinical discriminators of lobar and deep haemorrhages: the stroke data bank. Neurology 1992;41(12):1881-85

14. Garde A, Bohmer G, Seldon B, Neiman J. 100 cases of spontaneous intracerebral haematoma: Diagnosis, treatment and prognosis. Eur Neurol 1983;22:161-72

15. Kase CS, Williams JP, Wyatt DA, Mohr JP. Lobar intracerebral haematomas: Clinical and CT analysis of 22 cases. Neuroradiol (Ny) 1982;32:1146-54

16. Mukherjee N, Hazra BR. Evaluation of stroke patient with reference to $\mathrm{CT}$ scan finding. J Indian Med Assoc 1998;96(6):174-76

17. Wiggins WS, Moddy DM, Toole JF, Laster DW, Ball MR. 1978. Clinical and computerised tomographic study of hypertensive intracerebral haemorrhage. Arch Neurol 1998;5:832-33

18. Fieshci C, Carolei A, Fiorelli M, Argenlino C, Bozzao L, et al. Changing Prognosis of primary intracerebral haemorrhage: result of a clinical and CT follow up study of 104 patients. Stroke 1988;19(2):192-95

19. Michael ND, Dorothy FE, Allyson RZ. Hydrocephalus: A Previously Unrecognized Predictor of Poor Outcome from Supratentorial Intracerebral Haemorrhage. Stroke 1998;29:1352-57

20. Bamford J, Dennis M, Sandercock P, Burn J, Warlow C. The frequency, causes and timing of death within 30 days of a first stroke: the Oxfordshire community stroke project. J Neurol Neurosurg Psychiatry 1990;53:824-29

21. Anderson CS, Chakra TMH, Wynne EGS, Jamrozik KD. Spectrum of primary intracerebral haemorrhage in Perth, Western Australia, 1989 - 1990 : incidence and outcome. J Neurol Neurosurg Psychiatry 1994;57:936-40

22. Franke CL, Van Swieten JC, Algra A, Gijin JV. Prognostic factors in patients with intracerebral haemorrhage. J Neurol Neurosurg Psychiatry 1992;55:653-57

23. Silver FL, Norris JW, Lewis AJ. Early mortality following stroke, a prospective review. Stroke 1984;15:492-96 